\title{
The importance of tolerance and preference experiments for the interpretation of mesopsammon field distributions
}

\author{
BENGT-OWE JANSSON \\ Department of Zoology and Askölaboratory, University of Stockbolm, \\ Stockholm, Sweden
}

\begin{abstract}
EXTRAIT: L'importance d'experiments de tolerance et de préférence pour la compréhension de la distribution de mesopsammon dans la nature. La plage marine est un endroit propice aux études des problèmes fondamentaux de l'écologie marine. Des échantillons quantitatifs permettent d'étudier la distribution des animaux dans le réseau des gradients verticaux et horizontaux. Les causes de la distribution relevée doivent être élucidées par des expériences faites au laboratoire. Il est surtout indiqué de procéder à des expériences de tolérance et de préférence. Ces méthodes ont été appliquées à étude écologique du Copépode Harpacticide Parastenocaris vicesima qui colonise une plage de la Baltique. Les concentrations les plus importantes de cet organisme furent relevées entre 2 et $3,5 \mathrm{~m}$ du bord de la mer dans une salinité de 0,7 a $0,2 \%$ et la distribution verticale était très irrégulière. Les facteurs notés constitutifs du milieu sont: salinité, température, teneur en eau, accessibilité d'oxygène, granulométrie et teneur en matière organique. En plus de l'espèce étudiée il y avait une faune très riche dont les groupes dominants étaient: Oligochètes, Nématodes, Turbellariés. Au cours des expériences faites au laboratoire les organismes ont montré une grande résistance à des salinités basses et ils ont préféré une salinité de 2,5 à $0,5 \% \mathrm{~S}$. A une température de $30^{\circ} \mathrm{C}$ et dans des salinités de $5 \%$ et de $0,5 \%$ respectivement, $50 \%$ des animaux ont subsisté pendant 4 à 5 jours. Quant à l'accessibilité d'oxygène la limite inférieure était à $1 \times 10^{-7} \mathrm{gO}_{2} \mathrm{~cm}^{-2} \mathrm{~min}^{-1}$ et aucun individu n'a été récolté dans les couches de sable ayant une accessibilité inférieure à $1,9 \times 10^{-1} \mathrm{gO}_{2} \mathrm{~cm}^{-2} \mathrm{~min}^{-1}$. $P$. vicesima a préféré au laboratoire le sable ayant des grains d'un diamètre de 250-125 microns et n'a été relevé que dans les horizons caractérisés par ce type de sable. On peut s'attendre à trouver une pareille corrélation entre la distribution de la faune interstitielle et l'incidence des facteurs écologiques, mais seulement après des délais ayant permis aux animaux de rechercher leurs microhabitats normaux.
\end{abstract}

\section{INTRODUCTION}

The marine sandy beach is characterized by a net of horizontal and vertical gradients, the horizontal ones occur at right angles to the water-line, the vertical ones from the sand surface downwards. In this web of factor gradients, members of the interstitial fauna often react very conspicuously (JANsSON 1966a). The sandy beach offers therefore suitable studies on marine ecological principles: its factor gradients are straight and sometimes stable for long periods of time, during which the animals 
have opportunities to occupy their optimal microhabitats; the fauna is represented by a great number of systematical groups and different types of organization, the various reactions of which can be clearly studied.

Animals suddenly exposed to a non-optimal part of a gradient have only two possibilities: either to remain in the unsuitable environment or to move to a more optimal part of the gradient. Survival and adjustments in the former case involve such processes as "shock-response", "stabilization" and "new steady state of performance" (KINNE 1964). This does not necessarily imply a displacement of the original preferences as shown by JANSSON (1962). Such mode of reaction may be called "the tolerance type". In "the preference type of reaction" the animal moves along the gradient and may - if the conditions are stable enough - find an optimal area. In the analysis of field distributions the historic aspect of these dynamics must be duly considered. An aggregation of animals per se does not necessarily indicate their optimal zone if the environment conditions have not been stable for a sufficient period of time.

Once the field distribution of the animal has been studied by means of quantitative sampling, and measurements of the ruling environmental factors have been completed, the correlations of factors and fauna may be attempted. In the dense web of factor gradients, however, it is seldom possible to pinpoint the real cause of distribution from field studies only. Here, simple, parallel laboratory experiments provide additional means for a critical analysis. The need for such combined investigations has been stressed by K.INNE (1957).

A very simple, though useful type of laboratory experiment, is the resistance or tolerance experiment. One or several environmental factors are varied in a series of experiments and the length of survival periods is determined. The results may be plotted as LD 50-curves. The survival periods obtained for 50\% survival - "the Lethal Dose 50" - provides the measure for the degree of tolerance. Such information is, of course, a rather crude assessment of the test organism's requirements; it gives, however, clear end points for the activities of the animal. LD 50-series employing several variables will provide the optimal spectra of the test animal under laboratory conditions.

In the preference experiment, used either as an alternative experiment or as a gradient experiment, the animal is expected to choose its preferred intensity range of the factor amplitude offered. The physiological meaning of that range is not yet fully understood; I am inclined to assume that it may coincide with the lowest energy consumprion to the test animal. Together with the tolerance experiment it will deliver valuable information on the reactions of the animals and an inestimable help in the interpretation of field distributions.

The following study on the ecology of the harpacticoidean copepod Parastenocaris vicesima KLIE, comprising both quantitative studies in the field and laboratory experiments, will illustrate the suitability of the marine sandy beach for basic, ecological studies, and the importance of laboratory experiments as a valuable tool for the interpretation of field distributions. 


\section{MATERIAL AND METHODS}

The investigation was carried out on a sandy beach, about $0.5 \mathrm{~km}$ long, and located in the vicinity of the Askö Laboratory (the Swedish marine station in the Baltic) during June-August, 1966. The salinity of the region is 6 to $7 \% \mathrm{~S}$. The sea had been calm for several weeks, and its water-level sunk gradually about $20 \mathrm{~cm}$ during the two weeks preceding sampling. This period was sunny, and without rain. The conditions for the quantitative investigation must, therefore, be regarded as rather stable. During the day our field studies were conducted there was a clear sky and winds of 0-1 Beaufort, producing only very weak waves.

Of the sampling stations F, G, A, D (see diagrams), Station F, the most seaward one was always just covered by water; Station $G$ was seldom reached by the sea, and A only touched by very long, intermittent waves; Station $D$ was situated on the first crest of beams where a $10 \mathrm{~cm}$ thick layer of dry sand covered the surface (this layer was removed before sampling).

The quantitative sampling was made by forcing a brass tubing $(5 \mathrm{~cm}$ length, $10 \mathrm{~cm}^{2}$ cross-section) successively into the sand, and later, sliding a small tin plate underneath. Thereafter the sample was brought into the laboratory in small glass jars. The tin plate was carefully removed from the sand so that the next sample could be taken just where the overlaying one ended. All samples were first treated with $10 \%$ alcohol in order to anaesthetize the animals, then with $70 \%$ alcohol. The animals were stored in $70 \%$ alcohol and later collected by washing the sand 7 times with $70 \%$ alcohol of a volume 6 times that of the sample and each time decanting the floating animals and detritus. Tests showed that no specimens were left in the sand after such treatment.

The relative amounts of organic matter were estimated in animal samples, employing a scale from 0 to ++++ , where ++++ indicated samples in which $50 \%$ of the total volume was made up of detritus. For measurements of the various environmental factors holes were dug at the stations down to the hydrostatic ground water-level and probes inserted. Tests showed that the conditions in situ a few $\mathrm{cm}$ inside the walls of these holes remained undisturbed.

Salinity determinations were carried out in the laboratory on $1 \mathrm{ml}$ samples, which had been taken in the field with a syringe pipette. At Stations $G$ and A samples were taken near the sediment surface and at ground-water level; at Station D only ground-water samples were obtained in view of the possible lack of a vertical gradient (JANsson 1966b, and unpublished). For reasons given by Jansson (1962) salinity determinations were made on the basis of conductivity measurements; the values obtained are presented in brackets in the following text.

Temperature was measured with mercury thermometers, calibrated in $1 / 10^{\circ} \mathrm{C}$.

Oxygen availability was measured by means of a stationary platinum microelectrode (Lemon \& ERICKsson 1952). All values presented were obtained after a diffusion time of 3 minutes. Since the diffusion rate incorporates oxygen content, temperature, porosity and water-flow, it is ecologically a more suitable measure than the values of oxygen concentration generally used; for a further discussion see JANSSON (1966a). 
Moisture content of the sand was determined in the field by "Speedy Moisture Tester" (manufact. Messrs Thos. Ashworth and Co. Ltd. Burnley). The total weight of the sample was $26 \mathrm{mg}$; accuracy amounted to $\pm 0.2 \%$ wet weight. The sand samples were taken with a piece of polyvinyl-chloride tubing (inner diameter $16 \mathrm{~mm}$ ) the centre of which was inserted at the depths given.

Grain size was determined on the same samples from which the animals were taken; after sieving with Tyler screens cumulative curves were plotted for each sample in a semi-logarithmic diagram; however, these curves are not presented here in full.

\section{RESULTS OF FIELD STUDIES}

Field measurements of physico-chemical factors, except grain size, are plotted as profiles through the beach (each cross corresponds to one measurement). Expressing field conditions in terms of isotherms, isohalines etc. can, of course, produce only rough approximations since the number of measurements is comparatively small. Interpolation may sometimes seem rather optimistic, but numerous studies on this very beach over a period of several years have provided good guide posts for such plotting.

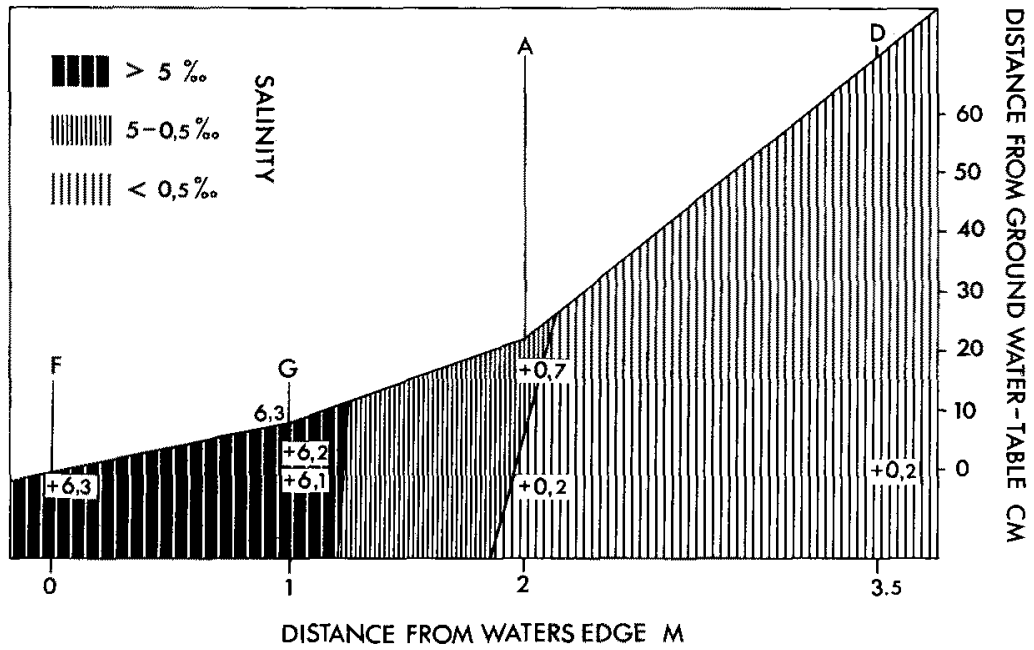

Fig. 1: Salinity conditions in Askö beach June 16, 1966. Each cross indicates one measurement

\section{Salinity}

The salinity gradient was very steep (Fig. 1); fresh water was encountered already at Station $A$ in the deeper layers $\left(250 \% 95 \times 10^{6}=0.2 \% \mathrm{~S}\right)$. The somewhat higher values at $5 \mathrm{~cm}$ depth are probably caused by weak wave action bringing in more salty water. Station D had almost the same salinity: $252 \varkappa_{25} \times 10^{6}=0.2 \% \mathrm{~S}$. Ten 
days earlier the salinity at $\mathrm{A}$ was $2.5 \%\left(4335 \%_{25} \times 10^{6}\right)$ but due to the successively sinking sea water-level the fresh water body from the continent had extended seawards. The conditions at Station D, however, remained constant.

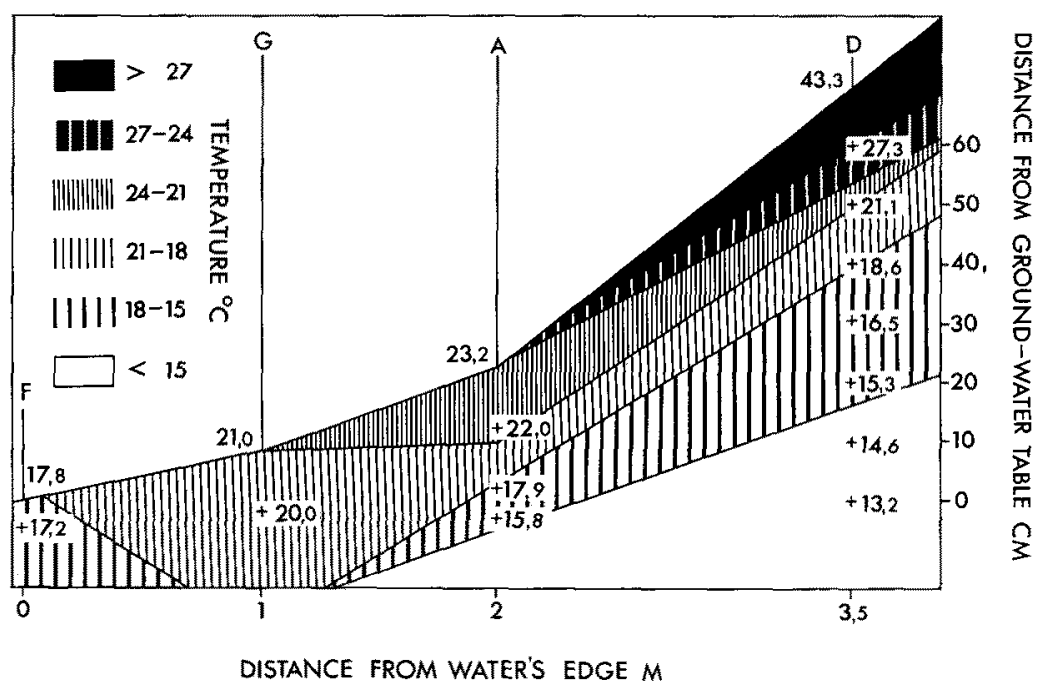

Fig. 2: Temperature conditions in Askö beach, June 16, 1966

\section{Temperature}

The distribution of temperature in the beach is shown in Figure 2. The dry surface layers have high temperatures with a maximum of $43.3^{\circ} \mathrm{C}$ but the temperature falls rapidly with increasing depth at Station $\mathrm{D}$. The deep penetration of the area $21^{\circ}$ to $18^{\circ} \mathrm{C}$ between $\mathrm{G}$ and $\mathrm{A}$ is probably due to the co-action between a favourable inclination to the sun and a better conduction of heat of this water-saturated part of the beach.

\section{Contents of interstitial water}

The content of water between the sand grains of the beach, expressed as percent wet weight, shows only a few anomalies (Fig. 3) which are due to irregularities in the grain size distribution (JANSSON 1966a). Generally the amount of water decreases successively with increasing distance from the water line and from the ground-water level with slightly higher values in the foreshore caused by wave action.

\section{Oxygen}

The oxygen availability is rather low in most parts of the beach, expecially in the upper layers at Station D (Fig. 4). The higher values on the surface of the fore- 


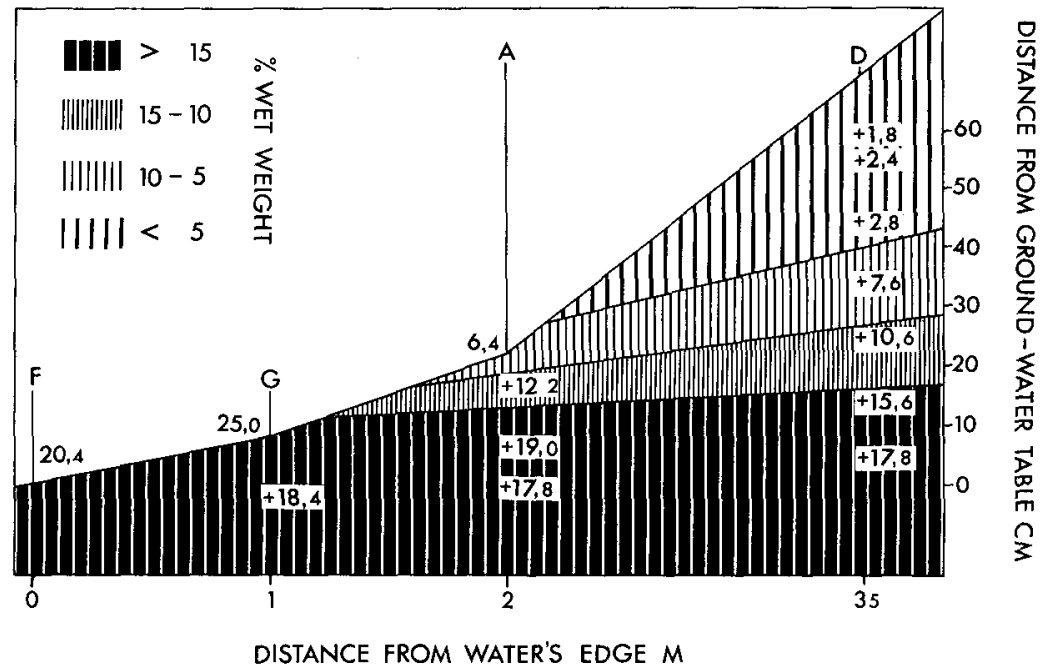

Fig. 3: Amounts of interstitial water in Askö beach, June 16, 1966

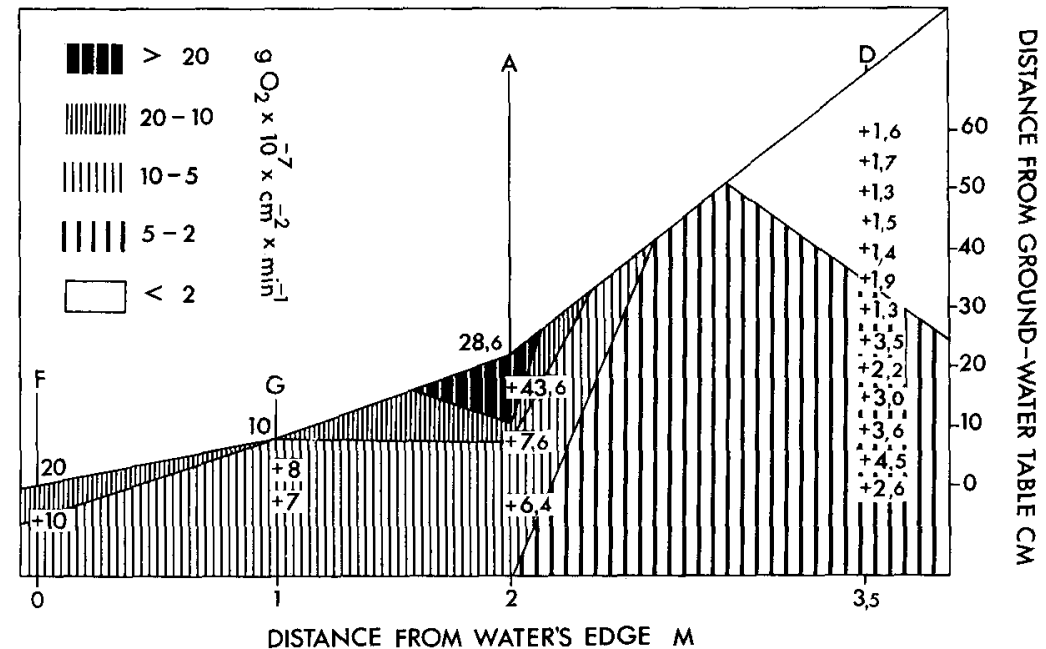

Fig. 4: Availability of oxygen at the beach. Each value represents the oxygen diffusion rate after 3 minutes of diffusion

shore are caused by wave action which will especially influence the non-saturated layers at Station A, where the sea water percolates the upper airfilled strata until it is stopped by the underlying water-filled pores and has to flow back into the sea. At Station D a slight increase in the availability of oxygen towards layers below ground-water level can be noticed. 


\section{Grain size}

If grain size distribution is plotted in terms of mean values, the whole shore appears to be very homogenous with a medium grain size of $400-800 \mu$ in diameter (Fig. 5). If the cumulative curves of each separate sample are compared, however, clear differences especially in regard to smaller grains become apparent. The mean grain size of the beach as a whole is roughly $600 \mu$.

If a number of equal spheres are arranged in any strictly systematic packing there exists, according to FRASER (1935), a certain diameter-ratio for spheres, which can

\begin{tabular}{|c|c|c|c|c|c|c|c|c|}
\hline \multicolumn{2}{|c|}{$F$} & \multicolumn{2}{|c|}{ G } & \multicolumn{2}{|c|}{ A } & \multicolumn{2}{|c|}{$D$} & \multirow[b]{2}{*}{$\begin{array}{l}\text { Depth } \\
\text { crn }\end{array}$} \\
\hline $\begin{array}{c}\% \\
<250 \mu\end{array}$ & $\begin{array}{l}\text { mean } \\
m m\end{array}$ & $\begin{array}{c}\% \\
<250 \mu\end{array}$ & $\begin{array}{l}\text { mean } \\
m \text { m }\end{array}$ & $\begin{array}{c}\% \\
<250 \mu\end{array}$ & $\begin{array}{l}\text { mean } \\
\mathrm{m} m\end{array}$ & $\begin{array}{c}\% \\
<25 \% \mu\end{array}$ & $\begin{array}{l}\text { mean } \\
m \mathrm{~m}\end{array}$ & \\
\hline 2.8 & 0.8 & 17.5 & 0.6 & 8.0 & 0.6 & & & 0.5 \\
\hline & & 4.2 & 0.8 & 18.5 & 0.4 & & & $5-10$ \\
\hline & & & & 12.9 & 0.6 & 16.2 & 0.5 & 10.15 \\
\hline & & & & 8.5 & 0.6 & 12.6 & 0.6 & $15-20$ \\
\hline & & & & 20.9 & 0.4 & 6.8 & 0.7 & $20-25$ \\
\hline & & & & & & 3.9 & 0.7 & $25-30$ \\
\hline & & & & & & 6.5 & 0.7 & $30-35$ \\
\hline & & & & & & 16.7 & 0.6 & $35-40$ \\
\hline & & & & & & 6.4 & 0.8 & $40-45$ \\
\hline & & & & & & 7.8 & 0.6 & $45-50$ \\
\hline & & & & & & 15.7 & 0.5 & $50-55$ \\
\hline & & & & & & 19.1 & 0.5 & $55-60$ \\
\hline & & & & & & 4.4 & 0.6 & 60.65 \\
\hline$x=0$ & & & & & & 2.6 & 0.7 & $65-70$ \\
\hline & & & & & & 4.2 & 0.7 & $70-75$ \\
\hline & & & & & & 17.7 & 0.5 & $75-80$ \\
\hline
\end{tabular}

Fig. 5: Distribution of grain size at the beach. Left columns of the four stations ( $F, G, A, D)$ express (in percent) the amount of total sample with grain diameters less than $250 \mu$

just pass through the pore necks into the interstitial voids of the larger spheres - "the critical ratio of entrance". If we assume - by a very broad generalization - the actual beach as consisting mostly of spheres with a diameter of $600 \mu$, FRASER's formula of loosest systematic packing $(0.414 \mathrm{D})$ and tightest packing $(0.154 \mathrm{D}$ : where $\mathrm{D}$ is the diameter of the spheres) will give critical ratios of 250 to $290 \mu$. That means that grains with diameters smaller than $250 \mu$ will fill the interstices between the larger grains, thus increasing the porosity and decreasing the sizes of the pore spaces. In Figure 5 the percentages of sand grains in the samples with diameters below $250 \mu$ are plotted. The individuality of the separate samples is now clearly shown: the top $5 \mathrm{~cm}$ at Station $\mathrm{G}$ contains a large portion of fine sand $(17.5 \%$ ) while the next lower layer has only small amounts $(4.2 \%)$. The samples can be divided into 2 categories separated by a clear gap, one with amounts above $12.6 \%$ (e. g. A $5-15 \mathrm{~cm}$, D 10-20, $35-40,50-60,75,80)$ and the other with amounts smaller than $8 \%$. 


\section{Organic matter}

The amount of visible organic matter is shown in Figure 6. It consisted mostly of floccular, half-decomposed, filamentous algae, especially Cladopohora with large amounts of epiphytic diatoms, mostly Epithemia sp. The outer Stations F and G had no visible organic content but Stations $A$ and $D$ had small to medium amounts. Two samples, however, were very rich: A 20 to $25 \mathrm{~cm}$ and D 25 to $30 \mathrm{~cm}$. In the field these layers appeared as broad, dark stripes in an otherwise homogenous matrix.

\section{Animals}

The fauna consisted mainly of enchytraeid worms, turbellarians and nematodes. The total number of animals, except harpacticids, was high especially in the samples G $0-15 \mathrm{~cm}, A$ 20-25 cm (enchytraeids), D 15-20, 35-70 and 75-80 cm, where the

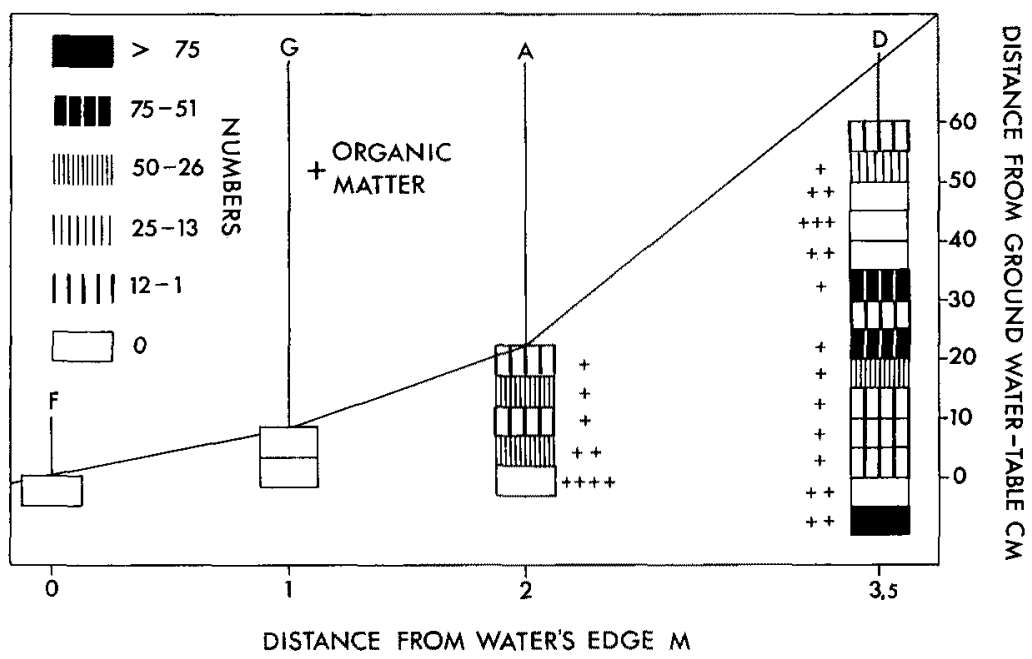

Fig. 6: Amount of organic matter and numbers of $P$. vicesima in each separate sample

numbers exceeded 100. The harpacticoidean fauna consisted nearly exclusively of $P a$ rastenocaris vicesima KuE with only a few irregularly distributed Parastenocaris phyllura KIEFER.

The distribution of $P$. vicesima is shown in Figure 6, which gives the number of specimens in each $50 \mathrm{~cm}^{3}$ sample. Stations $F$ and $G$ had no animals. In $A$ the total number of animals was $60\left(24 / 100 \mathrm{~cm}^{3}\right)$. In Station D the total number was 298 and the abundance $43 / 100 \mathrm{~cm}^{3}$. In neither station were the animals evenly distributed, but some samples had large numbers: A 5-10, 15-20 cm; D 35-40, 45-50 and 75-80. 


\section{CONCLUSIONS}

The beach offers some striking living conditions. Landwards from Station A is in fact a fresh water beach with high temperatures in the surface layers. The oxygen availability is greatest in the foreshore but very low in general. The pore system is characterized by originally wide pores due to the large amount of grains with diameters of about $600 \mu$, but these "primary" interstices are here and there filled by smaller grains resulting in irregularly distributed areas of tunnels and caverns of much smaller size. The supply of organic matter - important as food - is good in the backshore but very low in the foreshore. In some layers organic matter is so abundant, however, that it seems to affect the pore system (Stations $A$ at 20-25, and D at 25-30 $\mathrm{cm}$ depth).

On the basis of the field data alone it is tempting to explain the horizontal animal distribution as being caused primarily by salinity. This agrees well with the distribution of the species in the same locality a year before, when weather conditions had been similar (Jansson 1966). According to Nood (1957) $P$. vicesima is a typical species of the coastal ground-water with a preference for the mixooligohaline area. In the North Sea and the exposed shores in the "K.ieler Bucht" it was found far landwards but where the salinity of the sea was lower (e.g. in the Schlei and the Gulf of Finland; Nood 1953) the animals were distributed nearly to the waterline.

The temperature of the beach is rather moderate and should repel the animals only from the surface layers of the inner parts, where the low water content is already a limiting factor. The strata with a maximum amount of detritus cannot be accessible for the animals from mere considerations of space and are, indeed, completely devoid of $P$. vicesima.

The other animals are irregularly distributed and it is difficult to find any correlation to the distribution of $P$. vicesima. Since presumptive predators seem lacking and there is no shortage of food in this case, it can be expected that biotic factors are probably of small significance.

But how can the more detailed, vertical distribution of $P$. vicesima be explained? Laboratory experiments with the same population of animals may give further information.

\section{LABORATORY EXPERIMENTS}

\section{The experimental population}

All the $P$. vicesima used belong to the same population. They were collected at Station D on June 7, 1966 (salinity $0.2 \%$, temperature $11.5^{\circ} \mathrm{C}$ ) and were kept until the start of the respective experiments in the original water and detritus in the dark at $15^{\circ} \mathrm{C}$. The test animals were in good condition; a few specimens died; the numerous nauplii taken at sampling grew fast. $P$. vicesima appeared to be very active; it crawled rapidly among the detritus particles as if testing them for their food value. Though the test animals were very thigmotactic, they showed no clear negative phototaxis. 
Most test specimens were selected the day before the beginning of the experiment and kept in small glass jars overnight in habitat water. Thus weak specimens could be removed and the animal material be kept as homogenous as possible.

The experiments testing the tolerance both to salinity and temperature, were carried out in two parallel series with 10 specimens in each case. The different salinities were obtained by diluting marine water with distilled water; $5 \mathrm{ml}$ of each test concentration was poured into small glass jars into which the selected animals were pipetted. The animals were kept in the dark and examined once a day except the first two days when several observations were made. Specimens, showing no sign of movement at the touch of a preparation needle, were regarded as being practically dead and subsequently were removed. As the results of the two parallel series were nearly identical, both in regard to salinity and temperature-salinity experiments, the number of dead specimens at each observation was put together and presented as percentage values in LD 50-diagrams. The n-value of each diagram is 20 . The results were tested with rank-sum test according to Dixon \& MASSEY (1957 p. 289 ff.).

\section{Responses to salinity}

The results of the tolerance experiments at $15^{\circ} \mathrm{C}$ are shown in Figure 7 . The limit of $50 \%$ survival was not attained in either of the salinities between the habitat water and $10 \% \mathrm{~S}$ within 3 weeks. It is interesting to note that tolerance was greater in distilled water than in $15 \% \mathrm{~S}$. The optimum area of the animal is apparently located at very low salinities though the present data are not sufficient to separate the values within the range 5-0.1\% $\mathrm{S}$. The behaviour of the animals, however, gives further information. The locomotory activity in the different test concentrations 11 days after the start of the experiment was greatest in $0.5 \%$, where the animals behaved quite normally, nearly as great in $5 \%$ but considerably less in $0.1 \% \mathrm{~S}$. These rather subjective observations may be more conclusive when compared with the results of the preference experiments.

Preference experiments were carried out employing the technique described by JANSSON (1962). Kept in a small chamber, the animals were able to choose between two connecting sand layers, each of which was saturated with water of a distinct salinity concentration. The total number of animals $(n)$ is shown on each diagram. The alternatives $10 / 0.2 \% \mathrm{~S}$ were offered in one experiment only, whereas $5 / 0.2$, 2.5/0.2 and $0.2 / 0.1$ were used in two, five and two separate experiments respectively; the results of these are added. The total number of animals in each experiment was around 50. After equal numbers of the animals had been transferred to each side of the middle of the chamber, they moved between the sand grains at great speed. The chambers were kept in the dark at $15^{\circ} \mathrm{C}$ for three hours.

The results, statistically treated with the chi square test, are plotted in Figure 8. The preference zone of $P$. vicesima apparently lies somewhere between 2.5 and $0.1 \% \mathrm{~S}$. This is in good agreement with the observations of the conditions of the animals in the tolerance experiments. Both 10 and $5 \%$ S have a stong repelling influence on the animals. 


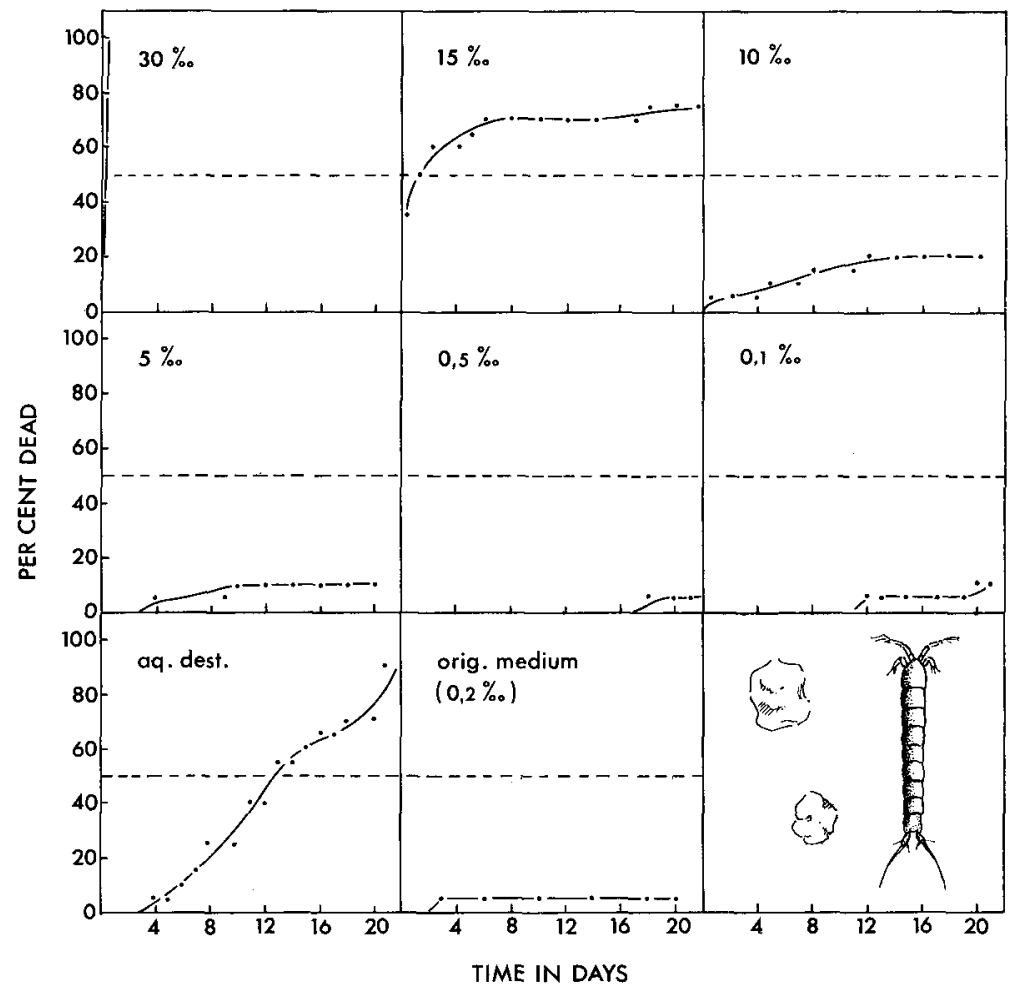

Fig. 7: Tolerance of $P$. vicesima to different salinity concentrations at $15^{\circ} \mathrm{C}$. June 19 to July 10,1966

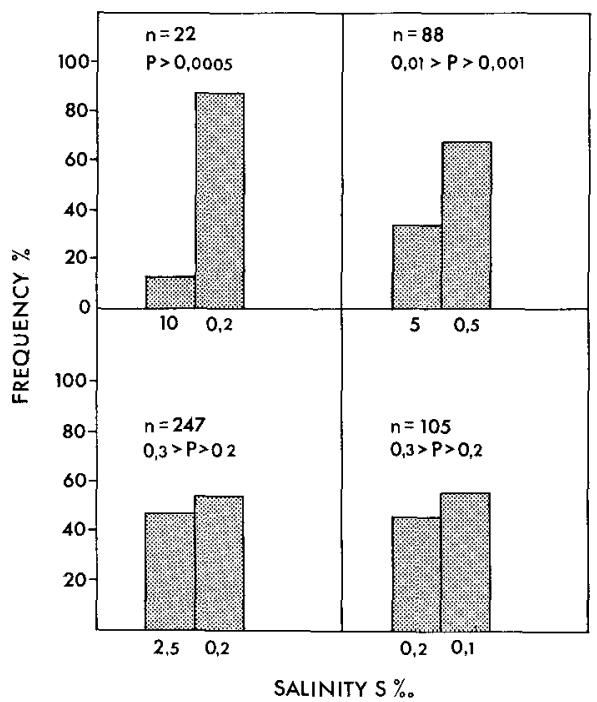

g. 8: Salinity preference of $P$. vicesima. June 14 to 23,1966 . $\mathrm{n}$ represents the total number of living specimens at the end of the experiment 


\section{Responses to temperature}

As the maintenance of the test animals in the laboratory had been successful at $15^{\circ} \mathrm{C}$ the animals were only tested for high temperature at $30^{\circ} \mathrm{C}$. The results are shown in Figure 9.

The much shorter survival time of $P$. vicesima in this high temperature is very striking. While survival times at $15^{\circ} \mathrm{C}$ amounted to weeks, in most of the test solutions LD 50-values in $30^{\circ} \mathrm{C}$ amounted to a few days only. Survival was best in 5 and $0.5 \% \mathrm{~S}$, and no significant difference existed between these. In $5 \%$ the last

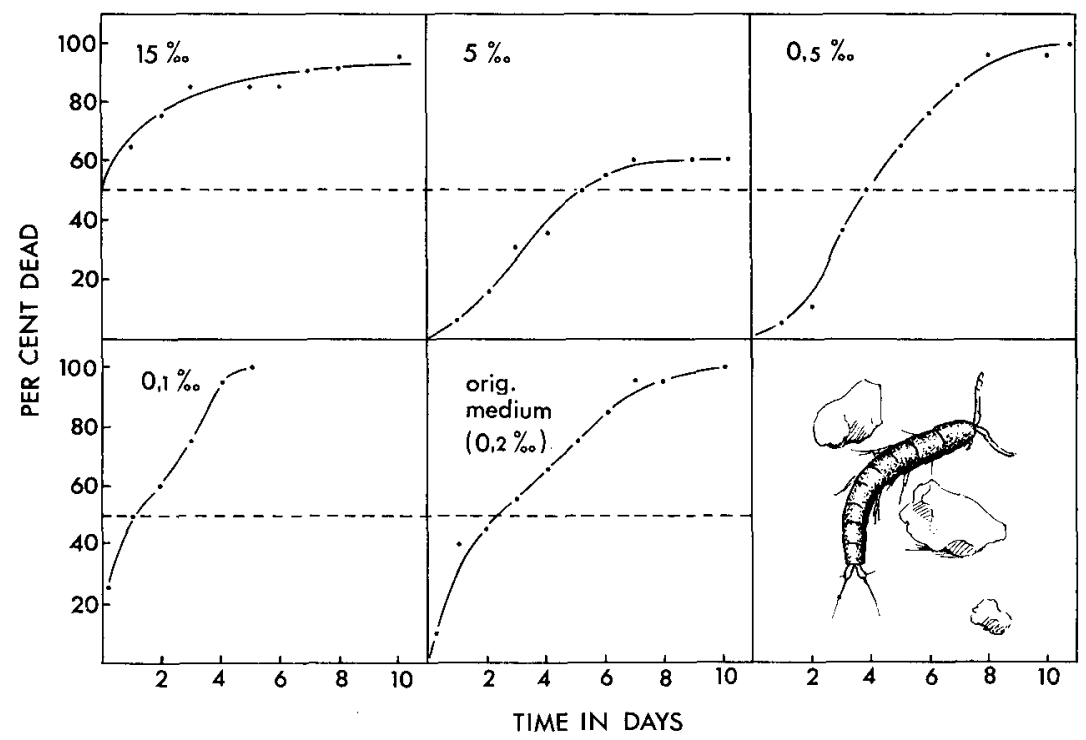

Fig. 9: Tolerance to high temperature $\left(30^{\circ} \mathrm{C}\right)$ in different salinity concentrations of $P$. vicesima. July 7 to 17,1966

specimen died on the 16th day of the experiment. Survival time in $0.1 \%$, however, was significantly shorter. The conditions of the animals were optimal in $0.5 \% \mathrm{~S}$. Thus from the temperature experiments it is evident that $30^{\circ} \mathrm{C}$ is a very high temperature for the animals and, again, that the salinity optimum is on the very limit to fresh water for this population.

\section{Tolerance to low oxygen availabilities}

As the oxygen values in the beach were very low especially at Station $D, P$. vicesima was tested at low oxygen availabilities. The concept of availability is quite new in animal ecology and, aside from the author, has only been applied to animals in detail by VAN GUNDY et al. (1962), who studied plant-parasitic nematodes in soil. Therefore a new experimental technique had to be worked out. 
The experimental cell consists simply of a $15 \mathrm{ml}$ vollpipette which has been cut according to Figure 10. A and sealed at the smaller end by a rubber stopper. The water with the animals, E, occupies the thin part, and its total volume after the animals had been added, was $0.17 \mathrm{ml}$. The capillary force kept the water within the tube so that the whole cell can very easily be handled horizontally under the microscope for the examination of the animals. Before the animals are added a piece of cotton is placed into the broad part of the cell and nitrogen is bubbled through the water for 15 minutes using a fine capillary. This is then lifted just above the water,

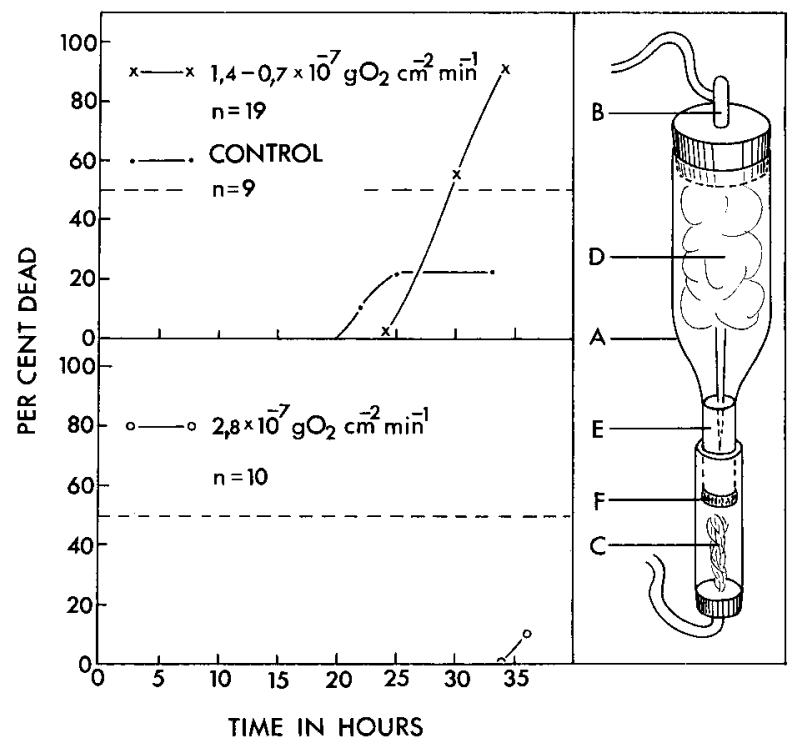

Fig. 10: L e $\mathrm{t}$ : Tolerance to low oxygen availabilities of $P$. vicesima. August 5 to $9,1966$. $\mathrm{R}$ ig h t : Experimental cell, adapted for oxygen diffusion rate measurements. $A$ cell, $B$ platinum microelectrode, $C \mathrm{Ag} / \mathrm{AgCl}$ electrode, $D$ cotton with pyrogallol solution, $E$ habitat water with animals, $F$ glassfilter separating cell from electrode

and the animals are added in a small volume of water $(0.02 \mathrm{ml})$. When the capillary has been withdrawn equal amounts of pyrogallol and $1 \mathrm{~N} \mathrm{NaOH}$ are pipetted into the cotton and the whole cell sealed with a rubber stopper. The alkaline solution of pyrogallol will reduce the amount of oxygen still left (Nicor 1929). Care must be taken to keep every trace of pyrogallol from the water but if everything has been made properly the cell can now be conveniently handled.

To determine the actual diffusion rate values, attained with the described technique, a platinum microelectrode (Fig. 10 B) was inserted through the rubber stopper and the cotton of one of the cells with the sensitive tip in the water. The $\mathrm{Ag} / \mathrm{AgCl}$ electrode consisted of silver wool in a piece of plastic tubing which was totally filled with $0.1 \mathrm{~N} \mathrm{KCl}$ and fastened to the lower end of the cell, separated from the water by a glass filter (F pore size $5-15 \mu$ ). This measuring cell was treated at the same time and in the same way as the experimental ones and the diffusion values obtained 
are also regarded as valid for these. When the treatment of the cells was completed and the rubber stoppers inserted the oxygen diffusion rate was $1.4 \times 10^{-7} \mathrm{~cm}^{-2} \mathrm{~min}^{-1}$ and remained constant during the first 18 hours. From 24 hours until the end of the experiment the availability was $0.7 \times 10^{-7} \mathrm{~cm}^{-2} \mathrm{~min}^{-1}$. The tightness of the measuring system became very apparent when the cell was opened 10 days later and the hitherto nearly white cotton grew rapidly dark brown at the access of oxygen.

The experiments were made with 9 to 10 specimens in each cell, which was also furnished with habitat water (salinity $0.2 \%$ ). They were kept in the dark and read at intervals according to the diagrams Figure 10. To test the possible negative effect of the pyrogallol itself, pointed out by NrCOL (1929), a cell was furnished with untreated water, animals, and a piece of cotton, saturated with the alkaline pyrogallol solution but with free access to air. The result is plotted in the diagram as "control". A higher diffusion rate (lower diagram) was obtained with untreated habitat water and absence of pyrogallol.

A certain negative effect of the pyrogallol solution cannot perhaps be fully rejected though the material is very small. But it can by no means explain the great differences between the other two LD 50-curves. These are caused by the difference in oxygen availability. At low values $\left(0.7-1.4 \times 10^{-7} \mathrm{~cm}^{-2} \mathrm{~min}^{-1}\right)$ LD 50 is attained after 29 hours, but in water of twice that value $90 \%$ of the animals are still alive after 35 hours.

\section{Grain size preference}

Although grain size is usually the only factor that most students of the interstitial fauna have taken into consideration, few experimental studies have been carried out. The most important ones have been summarized in the interesting work by GRAY (1966).

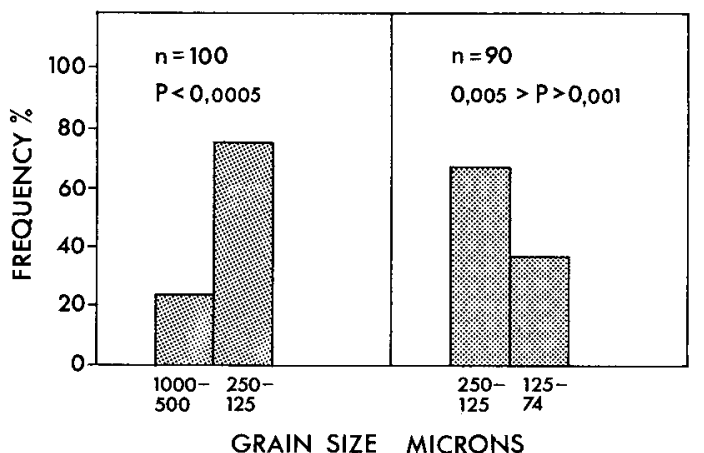

Fig. 11: Grain size preference of $P$. vicesima. July 2 to 3, 1966

In the present study a simple alternative chamber was used which has proved useful for experiments with many forms of the interstitial fauna. It consists of a piece of perspex tubing, the ends of which are closed by rubber stoppers. In the middle 
and top of the tube a hole is drilled, large enough for the insertion of pipettes. A vertical slit is cut through the middle of the hole parallel to the ends of the tube and half way through. Here a plate of perspex circular at the lower end, can be inserted to separate the inside of the tube into two water-tight halves. In each half $0.5 \mathrm{~cm}^{3}$ sand is poured, this consists of natural beach sand, washed, dried and sieved. The perspex plate is removed and the sand saturated with water from the habitat. The substrate is packed thoroughly by repeatedly tapping the chamber against the table and the surplus water sucked off with a pipette until the surface of the sand is nearly dry. This will restrict the animals to the interstices of the sand, forcing them to choose the most suitable pore size. The animals are transferred in equal numbers to each side of the middle line, the chamber is sealed and kept in the dark. The duration of the experiment will depend on the activity of the species. The perspex plate is then inserted and the sand and animals in each half washed out. The absence of angles and corners in the chamber facilitates the removal of the animals.

In the present experiment, 50 full-grown $P$. vicesima were transferred to each side of the middle line and kept in the dark at $15^{\circ} \mathrm{C}$ for three hours. Only two experiments were made, which are plotted in Figure 11. The n-values represent the number of living animals after the experiment.

As is clearly seen the animals show a strong preference for grains of 250 to $125 \mu$ in diameter. After the transfer they were studied under the binocular for a while. In 250 to $125 \mu$ they moved skillfully between the sand grains and with great rapidity but in sand of 1000 to $500 \mu$ the pores were larger and the animals had greater difficulty in getting sufficient support from the grain walls. In 125 to $74 \mu$ the interstices were so small that the animals had to force their way through the sand. After the experiment, when the sand and the animals were poured into a petri-dish, it was obvious, that the animals actively sought the spots where the sand grains lay in several layers and always returned to the thicker layers when they reached the edges of the sandy area.

No experiments on photo-taxis have been made. $P$. vicesima has, however, never shown any definite reactions with respect to light, therefore, thigmotactic reactions seem to play an important role in the life of P. vicesima. Its body, enlongated and wormlike, is adjusted to movements in close contact to the surface of sand grains; this mode of locomotion was characterized by REMANE (1933) as "stemmschlängeln".

There is thus every reason to assume that, in the field, $P$. vicesima would prefer strata where great portions of fine sand make the pore sizes equal to those in sand of 250 to $125 \mu$ grain size.

\section{THE CAUSES OF THE FIELD DISTRIBUTION OF $P$. VICESIMA}

The salinity experiments strongly suggest a positive correlation between the horizontal distribution of $P$. vicesima and the salinity gradient. The lack of animals at Stations $F$ and $G$ is surely the results of an escape response caused by salinities above $5 \% \mathrm{~S}$. 
The vertical distribution at the inner Stations $A$ and $D$ is more complex. Relevant factors are: amount of organic matter, oxygen availability and grain size. The two most heavily detritus-filled layers contained no animals. The critical value of low oxygen availability lies between 1 to $2 \times 10^{-7} \mathrm{~cm}^{-2} \mathrm{~min}^{-1}$. The animals showed a clear preference for grain sizes of 250 to $125 \mu$. All these repellent and attracting factor intensities are plotted in the same diagram (Fig. 12).

In Station A three strata have a favourable grain size, the deepest of these, however, is completely closed to the animals because of the very great amount of detritus. This fact is in good agreement with the distribution in the field.

\begin{tabular}{|c|c|c|c|c|}
\hline $\begin{array}{l}\text { OEPTH } \\
\mathrm{CM}\end{array}$ & $\mathrm{O}_{2}$ & DEFRTUS & $\begin{array}{l}\text { GRAIN } \\
\text { SIZE }\end{array}$ & NUABERS \\
\hline $0-5$ & & & & 4 \\
\hline $5-10$ & & & 18,5 & 24 \\
\hline $10-15$ & & & 12,9 & 8 \\
\hline $15-20$ & & & & 24 \\
\hline $20-25$ & & ++++ & 20,9 & - \\
\hline
\end{tabular}

A

\begin{tabular}{|c|c|c|c|c|}
\hline $\begin{array}{l}\text { DEPTH } \\
\text { CM }\end{array}$ & $o_{2}$ & Detritus & $\begin{array}{c}\text { GRAIN } \\
\text { SIZE } \\
\end{array}$ & NUMBERS \\
\hline $10-15$ & & & 16.2 & 3 \\
\hline $15-20$ & & & 12,6 & 17 \\
\hline $20-25$ & $1,3-1,5$ & & & - \\
\hline $25-30$ & $1,5-1,4$ & +++ & & - \\
\hline $30-35$ & $1,4-1.8$ & & & - \\
\hline $35-40$ & & & 16.7 & 69 \\
\hline $40-45$ & & & & 4 \\
\hline $45-50$ & & & $x$ & 56 \\
\hline $50-55$ & & & 15.7 & 43 \\
\hline $55-60$ & & & 19,1 & 1 \\
\hline $60-65$ & & & & 1 \\
\hline $65-70$ & & & & 1 \\
\hline $70-75$ & & & & - \\
\hline $75-80$ & & & 17,7 & 103 \\
\hline
\end{tabular}

Fig. 12: Distribution of animals at Stations $A$ and $D$ in connection to relcvant environmental factors. Symbols : black $=$ repellent, grey $=$ indifferent, white $=$ attracting laycrs. $\mathrm{O}_{2}$ is expressed as $\mathrm{gO}_{2} \times 10^{-7} \mathrm{~cm}^{-2} \mathrm{~min}^{-1}$, grain size as percentages of total sample of grain diameters less than $250 \mu$

At Station $D$ the layers between 20 and $35 \mathrm{~cm}$ depth have too small oxygen availability values $\left(1.3\right.$ to $\left.1.9 \times 10^{-7} \mathrm{~min}^{-1}\right)$ and one of these contains also too much organic matter; this coincides very well with the vertical distribution - they are totally absent here. Great percentages of sand with grain sizes less than $250 \mu$ exist in several layers. All of these except one $(55$ to $60 \mathrm{~cm}$ ) contain large numbers of $P$. vicesima. The layers between 60 and $75 \mathrm{~cm}$ depth have very small fractions of fine sand, which are surely responsible for the absence of animals.

Two layers contain large numbers of $P$. vicesima even though they are in the diagram classed as "indifferent" as to their properties: $A$ at 15 to $20 \mathrm{~cm}$ and D at 45 to $50 \mathrm{~cm}$ depth. A comparison with Figure 5 shows, however, that the percentage of fine sand is ranked in the top of the second category with values of 8.5 and 7.8 
respectively. Furthermore they are directly connected to the above indicated, well populated centres. The are, therefore, by no means exceptions from the general scheme, outlined above.

The present investigation has shown, that the distribution of Parastenocaris vicesima is strongly governed by oxygen availability, grain size and salinity. The intimate correlation between field distributions and the gradient web of these factors is the result of stable weather conditions for several weeks, allowing the attracting or repellent factor intensities to affect $P$. vicesima for a long period of time. Under circumstances of fast changes in climatic conditions the animals may not have enough time to find their preferences owing to their relatively small locomotory ability. The most appropriate way of studying the dynamics of a sandy beach, is by taking "snapshots" of their distribution after periods of carefully registered environmental conditions, and by selecting conditions which are typical for different types of weather.

\section{SUMMARY}

1. Marine sandy beaches allow interesting basic studies on animal distribution and other marine ecological aspects.

2. The field distributions observed should be accompanied by laboratory experiments in order to establish the specific effects of the different environmental factors. The use of tolerance and preference experiments as simple and highly successful tools is discussed.

3. The distribution of the copepod Parastenocaris vicesima KLIE in a sandy beach on Askö (Baltic Sea) has been investigated and tested in laboratory experiments. Measurements of salinity, temperature, water content, oxygen availability, grain size and organic matter in four successive beach stations are presented.

4. $P$. vicesima was absent in the two most seaward stations and the vertical distribution in the two inner stations seemed rather irregular.

5. Tolerance experiments with 8 different salinity concentrations showed the greatest survival in 10 to $0.1 \% \mathrm{~S}$. Preference experiments revealed a preference zone at 2.5 to $0.1 \%$.

6. Tolerance to high temperature was tested at $30^{\circ} \mathrm{C}$ in 5 different salinities. The survival was best in 5 to $0.5 \%$.

7. A simple apparatus for testing the responses of small animals to low oxygen availabilities was constructed. A lower tolerance limit in habitat water of $15^{\circ} \mathrm{C}$ was located around $1 \times 10^{-7} \mathrm{gO}_{2} \mathrm{~cm}^{-2} \mathrm{~min}^{-1}$.

8. In preference experiments with different grain sizes, $P$. vicesima preferred sand with a medium grain size of $250 \mu$.

9. The results of our laboratory experiments could be used to explain the field distributions of $P$. vicesima observed. The lack of animals in the outer station was caused by the salinity factor. The vertical distribution in the inner stations was a result of the combined effects of (a) detritus concentration, (b) oxygen availability and (c) great percentages of fine sand, which attracted the animals in several layers.

10. The necessity of knowing the local weather conditions which were effective during the period previous to the field investigations is stressed. 


\section{LITERATURE CITED}

Dixon, W. J. \& Massey, Jr., F. J., 1957. Introduction to statistical analysis. 2nd ed. McGrawHill, New York, 488 pp.

FrASER, H. J., 1935. Experimental study of the porosity and permeability of clastic sediments. J. Geol. 43, 910-1010.

GraY, J. S., 1965. Selection of sands by Protodrilus symbioticus Giard. Veröff. Inst. Meeresforsch. Bremerh. (Sonderbd) 2, 105-116.

Gundy, S. D. van, Stolzy, L. H., Szuszkiewicz, T. E. \& Rackham, R. L., 1962. Influence of oxygen supply on survival of plant-parasitic nematodes in soil. Phytopathology 52, $628-632$.

JANsson, B. O., 1962. Salinity resistance and salinity preference of two oligochaetes Aktedrilus monospermatecus KNöllNer and Marionina preclitellocbaeta n. sp. from the interstitial fauna of marine sandy beaches. Oikos, 13, 293-305.

- 1966a. Microdistribution of factors and fauna in marine sandy beaches. Veröff. Inst. Meeresforsch. Bremerb. (Sonderbd) 2,77-86.

- 1966b. On the ecology of Derocbeilocaris remanei Delamare \& Chapruis (Crustacea, Mystacocarida). Vie Milieu (Sér. Biol. mar.) 17, 143-186.

KInNE, O,, 1957. Physiologische Okologie - ein modernes Forschungsgebiet. Gedanken zur Problematik und Methodik der Okologie. Biol. Zbl. 76, 475-485.

- 1964. Non-genetic adaptation to temperature and salinity. Helgoländer wiss. Meeresunters. 9, 433-458.

Lemon, E. R. \& Erickson, A. E., 1952. The measurement of oxygen diffusion in the soil with a platinum microelectrode. Proc. Soil Sci. Soc. Am. 16, 160-163.

Nicol, H., 1929. Note on anaerobiosis and the use of alkaline solutions of pyrogallol. Biochem. J. 23, 324-326.

Noopt, W., 1953. Entomostracen aus dem Litoral und dem Küstengrundwasser des Finnischen Meerbusens. Acta Soc. Fauna Flora fenn. 72, 1-12.

- 1957. Zur Okologie der Harpacticoidea (Crust. Cop.) des Eulitorals der deutschen Meeresküste und der angrenzenden Brackgewässer. Z. Morph. Okol. Tiere 46, 149-242.

Remane, A., 1933. Verteilung und Organisation der benthonischen Mikrofauna der Kieler Budht. Wiss. Meeresunters. (Abt. Kiel) 21, 161-221.

\section{Discussion following the paper by Jansson}

BARNES: Your approach to measuring oxygen in the sand is indeed an attempt to get a result of real ecological value. Would you please give details?

JANSSON: Details about the method I have used have been published by LEMON \& ERICKSson (1952). The cathode consists of a stationary platinum microelectrode, the anode of $\mathrm{Ag} / \mathrm{AgCl}$. Between these a voltage of $0.8 \mathrm{~V}$ is applied. First the oxygen at the Pt-electrode surface is reduced, giving a high spike in the current measured. After 3 minutes a steady state is attained, and here I have taken my values. In the beaches studied (ordinary beaches without stagnant water) I have noticed no drift in the values. This summer, however, I have, in collaboration with Dr. FENCrrer, Helsingør (who performed parallel measurements of redox potentials), studied the oxygen diffusion rate in a small beach with varying amounts of $\mathrm{H}_{2} \mathrm{~S}$. In such layers, of course, we can expect poisoning of the electrode, but we got reliable oxygen values outside the zones of the strongly reducing conditions. Our studies will be published this year in "Ophelia".

Barnes: Is it possible to use the same technique to measure oxygen transport across tissue boundaries in isolated tissues or whole organisms in the laboratory?

Jansson: The method can be applied to living organisms or tissues, because the electrode is simple to make and to adjust to different needs. 